\title{
The impact of demographic factors on work-family conflict and turnover intentions in the hotel industry
}

\author{
Jelena Tepavčević ${ }^{1}$, Svetlana Vukosav ${ }^{1}$, Milan Bradić ${ }^{1 *}$ \\ ${ }^{1}$ University of NoviSad, Faculty of Science, Department of Geography, Tourism and Hotel \\ Management, Novi Sad, Serbia
}

\begin{abstract}
Family and work are the most important aspects in an individual's life, and the primary goal is to find a balance between these two. Given the characteristics of working in the hotel industry, employees in this industry very often face a conflict between family and work. This study aims to meas ure theimpact of socio-demographic characteris tics (gender, age, education and marital status) on work-family conflict (WFC) and turnover intentions (TI). On the sample of 1.100 employees in different hotel facilities by applying t-test and analys is of variance ANOVA, it was found that tested socio-demographic characteristics are not significant indicators of experiencing WFC, but age and marital status are proven to be significant determinants of turnover intentions. Results obtained in this study can help managers to understand antecedents and consequences of experiencing work-family conflict and to undertake activities to reduce these conflicts and turnover intentions of employees.
\end{abstract}

Keywords: services, hotel industry, lodging, work-family conflict, turnover intentions JEL classification: L83, J63, J24, Z31

\section{Uticaj socio-demografskih karakteristika na konflikt između posla i porodice i namere o napuštanju posla u hotelijerstvu}

Sažetak: Porodica iposao su među najvažnijim s ferama života pojedinca, a primarni cilj je nalaženje ravnoteže između njih. S obziromna os obenosti rada u hotelijerstvu, zapos leni se čes to susreću sa konfliktom uzrokovanim obavezama u porodičnom životu i na poslu. Cilj rada je merenje uticaja socio-demografskih karakteristika (pol, starosna dob, nivo obrazovanja i bračni status) na konflikt posao-porodica i namere o napuštanju posla. Na uzorku od 1.100 ispitanika u različitim hotelijerskim objektima primenom t-testa i analize varijanse ANOVA, pokazalo se da nema razlika u doživljavanju konflikta posao-porodica u odnosu na testirane socio-demografske karakteristike, ali kada je u pitanju namera napuštanja pos la, postoje s tatis tički značajne razlike u odnosu na starosnu dob i bračni status. Rezultati dobijeni ovimis traživanjemmogu pomoći menadžerima da razumeju antecedente i pos ledice

* milanbradic@gmail.com

This article is an open access article distributed under the terms and conditions of the Creative Commons Attribution (CC BY) license (http://creativecommons.org/licenses/by/4.0/). 
doživljavanja konflikta između posla i porodice i da preduzmu aktivnosti kako bi smanjili ove konflikte i namere o napuštanju posla kod zaposlenih.

Ključne reči: usluge, hotelijerstvo, konflikt pos ao-porodica, namere o napuštanju pos la JEL klasifik acija: L83, J63, J24, Z31

\section{Introduction}

As the two most important spheres in the lives of individuals, work and family often come into conflict, and their influence is an indicator of success and life satisfaction in general. Work is usually necessary for the normalfunctioning of the family, but it often happens to affect the disintegration and instability of the family members. The increased number of employed women reduces the time that spouses spend participating in joint family activities. This development has led to a series of problems that inevitably affect the emergence of conflicts between these two spheres of human life. As stated by Netemeyer et al. (1996) family-work conflict (FWC) is a kind of interrole conflict in which the overall demands of the family, as well as time dedicated to it, and the pressure created by the family interfere with completing work-related duties. On the other hand, the same authors defined workfamily conflict (WFC) as a type of interrole conflict in which the overall demands of the work, as well as time dedicated to it, and the pressure created by the work interfere with completing family-related duties. The existence of conflicts between family and work, as well as between work and family, negatively affects work performance, health, but also the satisfaction with various aspects of life. Due to this, it is important to strive to establish work-life balance. As claimed by several authors, work-life balance could be characterized as an absence of work-family conflict along with high levels of work-family enrichment (Du xbury \& Higgins, 2001; O’Driscoll et al., 2006). In many industries, the aim is to reduce the time spent at work and away from the family, while in the hospitality industry this is not the case because most jobs are impossible without a key factor - people. In addition to the above, work in the hos pitality industry is different from work in other industries because employees in hotels and restaurants work when mostemployees in other industries are free (e.g. at weekends and national holidays). Studies that have addressed this is sue show that employees in the servicesector are more susceptible to family and work conflict (Furnham, 2002; Netemeyer et al., 2005). Susceptibility to these conflicts can be explained by the fact that cus tomer relationships are often very fierce and stressful, which is later transferred to employees' homes (Netemeyer et al., 1990; Netemeyer et al., 2005). On the other hand, some authors believe that not only work is a factor which affects the existence of this conflict, but also those family duties can affect the disruption of work obligations (Choi \& Kim, 2012; Poelmans et al., 2003).

Employees who are faced with a conflict between family and work become emotionally exhausted, and these two forms of conflict (WFC and FWC) are notable predictors of employment change (Yavas et al., 2008). The occurrence of problems at work has immediate and negative effects on the family (Turliuc \& Buliga, 2014). The same authors state that the conflict between family and work is the main antecedent of the turnover intention (TI), which explains the high rate of labour turnover in the hotel industry.

\section{Literature review}

\section{Impact of gender on work-family conflict and turnover intentions}

Research that has addressed gender differences and conflicts between work and family has yielded various conclusions. Some studies haveshown that women express the presence of 
these conflicts more than men (Frankenhaeuser et al., 1989; Lundberg et al., 1994), while others pointed out that genderhas no effect on the conflict between family and business life (Akintayo, 2010; Frone, 2003; Karatepe et al., 2010). Research in the field of hospitality industry indicated that female employees report higher levels of WFC and FWC than male (Fiksenbaum et al., 2010; Tromp \& Blomme, 2014; Yavas et al., 2008). In addition, some authors have indicated that gender is a factor of turnover intention, i.e. that women show a higher degree of turnover intention than men (Emiroğlu et al., 2015). Contras tingly, Carbery et al. (2003) and Yavas et al. (2008) found no influence of gender on turnover intention. Chen et al. (2018) found out that male hotel employees who experienced a higher level of WFC have higher intention to leave an organization than female hotel employees.

Based on this, the authors proposed the following hypotheses:

$\mathrm{H}_{1}$ : There are significant differences in experiencing WFC according to gender.

$\mathrm{H}_{2}$ : There are significant differences in expressing TI according to gender.

\section{Impact of age on work-family conflict and turnover intentions}

Age has been found as a factor that contributes to experiencing WFC and intent to leave an organization. Specifically, Gordon and Berry (2007) have indicated that, in the early stage of their careers, people are frequently willing to forfeit their personal lives in light of legitimate concern for their professional progression. Various researches indicated inconsistency in findings. For example, several authors pointed to negative association between age and WFC (Andreassi \& Thompson, 2007; Grzy wacz \& Marks, 2000; Hsu, 2011). Contrary to their results, Mjoliet al. (2013) found positive association between age and WFC. On the other hand, Karatepe et al. (2010) did not found any significant correlation between WFC and age. Age was found as a determinant of turnover intention; and the turnover intention is generally lower among older employees (Blomme et al., 2010; Carbery et al., 2003; Karatepe et al., 2006; Kim et al., 2010; Pizam \& Thornburg, 2006).

Based on this, the authors proposed the following hypotheses:

$\mathrm{H}_{3}$ : There are significant differences in experiencing WFC according to age.

$\mathrm{H}_{4}$ : There are significant differences in expressing TI according to age.

\section{Impact of education level on work-family conflict and turnover intentions}

The influence of education level on WFC has been recognized in the literature. Higher educated people would acquire more chances of advancement or working away, which increas es the possibility of WFC (Adams et al., 1996). Anafarta and Kuruüzüm(2012) found that increasing the level of education in both males and females leads to an increase in the level of WFC they face with. Contrary to this, Carnicer et al. (2004) indicated that level of education has noevident effect on WFC. In some studies, the relationship between education level and turnover intentions has been examined. There is a positive relationship between the level of education and turnover intention, i.e. people with a lower level of education have a less pronounced intention to leave the organization (Carbery et al., 2003). On the other hand, in the study of Karatepe et al. (2006), a negativeconnection was found between education level and TI, i.e. that more educated employees express les s turnover intention. Blomme et al. (2010) explore the association between flexibility in the workplace, organizational support, WFC, and the turnover intention among highly educated employed respondents in hotels. Their results indicate that the WFCand organizational support significantly explain the intentions of highly educated employed respondents to leave the organization.

Based on this, the authors proposed the following hypotheses: 
Tepavčević, J. et al. - The impact of demographic factors on work-family conflict and turnover intentions in the hotel industry - Hotel and Tourism Management, 2021, Vol. 9, No. 2:25-36

$\mathrm{H}_{5}$ : There are significant differences in experiencing WFC according to education level.

$\mathrm{H}_{6}$ : There are significant differences in expres sing TI according to education level.

\section{Impact of marital status on work-family conflict and turnover intentions}

Various studies have examined the impact of marital status on WFCand intentions to leave an organization. In several studies, a negative impact of marital status on WFC was found (Beutell, 2010; Mukanzi \& Senaji, 2017; Rathi \& Barath, 2013). On the other hand, Liu et al. (2020) found no significant as sociation between marital status and WFC. Besides its impact on WFC, marital status is one of the determinants for leaving an org anization (Carbery et al., 2003). The rate of leaving the organization is lower among married people than among singles (Carbery et al., 2003; Emiroğlu et al., 2015).

Based on this, the authors proposed the following hypotheses:

$\mathrm{H}_{7}$ : There are significant differences in experiencing WFC according to marital status.

$\mathrm{H}_{8}$ : There are significant differences in expressing TI according to marital status.

\section{Methodology}

The research was carried out on the territory of the Republic of Serbia among employees in various types of hotel facilities. The study included 64 hotels, 21 garni hotels, 3 tourist resorts, 3 motels and 1 pension. The employees were surveyed using a face-to-face technique in order to increase the response rate, as well as to eliminate potential ambiguities during the completion of the questionnaire. A total of 1,130 employees in different positions and in different sectors were surveyed. 30 questionnaires were eliminated from further processing due to mis sing data, so responses of 1,100 employees were included in further analys is. The questionnaire used to measure WFC and TI of hotel employees in Serbia consisted of two parts. The first part referred to sociodemographic data of respondents (gender, age, level of education, marital status). The second part contained items that were grouped into five factors (Work - Family Conflict - WFC, Family - Work Conflict - FWC, Emotional Exhaustion, Job Performance and Turnover Intentions). The research was based on the study of Yavas et al. (2008) who conducted the res earch among employees in executive positions in hotels with $3 *, 4 *$ and $5 *$. The factors were taken completely and there was no need for their modification. The first factor, Work-Family Conflict included 5 items that referred to the inability to performfamily obligations due to work. Given that this conflict is two-way, the second factor Family-Work Conflict, consisted of 5 items that are related to the lack of work obligations performance due to family. The Emotional Exhaustion factor consisted of 8 items related to burnout and exhaustion at work. Within the Job Performance factor, employees expressed their perceptions of commitment at work through 5 items. The last factor, Turnover Intentions, consisted of 3 items related to the intentions of employees to leave the organization. A five-point Likert scale was used to express the degree of agreement with the statements within the factors ( 1 - I do not agree at all, 5 - I completely agree). Higher scores indicate a higher degree of presence of these conflicts, emotional exhaustion, perception of work performance, as well as turnover intention.

\section{Results}

Out of a total of 1,100 respondents, approximately the same number of employees are male (47\%) and female (53\%). Most respondents belong to the age category between 26 and 35 years $(39.1 \%)$ and the least are older than 55 years $(4.5 \%)$. Pertaining to marital status, almost half of the total number of employed respondents are married (48.8\%), and a very 
small percentage are widowed (1.6\%) as well as those in other types of partnerships $(1.7 \%)$. Observing the level of education of the respondents, it can be noticed that the majority of res pondents have completed high school $(56.3 \%)$, but the share of highly educated $(33.8 \%)$, as well as those with completed magistrate/master studies $(9.6 \%)$ is also satisfactory (Table $1)$.

Table 1: Sociodemographic characteristics of respondents

\begin{tabular}{|l|c|}
\hline \multirow{2}{*}{ Gender } & $\begin{array}{c}\text { Number of } \\
\text { respondents }\end{array}$ \\
\cline { 2 - 2 } Fale & 529 \\
\hline Age & 571 \\
Up to 25 years & 156 \\
26 - 35 years & 430 \\
$36-45$ years & 302 \\
46 - 55 years & 162 \\
Over 55 years & 50 \\
\hline Marital status & \\
Married & 537 \\
Single/Unmarried & 436 \\
Divorced & 90 \\
Widowed & 18 \\
Other & 19 \\
\hline Education & \\
High School & 619 \\
College/Faculty & 372 \\
Magistrate/Master & 106 \\
PhD & 3 \\
\hline
\end{tabular}

Source: Author's res earch

The results of the descriptive statistical analysis are given in Table 2. Analysing the values of each factor, it is found that the factor with the highest mean is JP (3.3593), while the factor with the lowest mean is FWC (1.9565). Comparing the mean values of factors FWC (1.9565) and WFC (2.5324), it could be concluded that employees in the hotelindustry in Serbia face WFC more than FWC. Guided by the fact that work in the hotel industry is very intense and specific, because employees make daily contacts with guests and working with people, it was ass umed that res pondents would expres s a high level of emotional exhau stion. Factor EE has the mean value is 2.6095 , and such low value were not expected. Statements within the factor TI have almost equal values that are very low. In addition to descriptive statistical analysis, the reliability of the questionnaire was also analysed. The Cronbach Alpha coefficient of the overall scale is 0.919 , and the values of the coefficients of individual factors are shown in Table 2. Reliability analys is found that the Cronbach Alpha coefficient for all factors exceeds the recommended value of 0.7 (Kaiser, 1974), indicating that all factors are in the high-reliability domain. 
Tepavčević, J. et al. - The impact of demographic factors on work-family conflict and turnover intentions in the hotel industry - Hotel and Tourism Management, 2021, Vol. 9, No. 2:25-36

Table 2: Results of descriptive statistical analys is

\begin{tabular}{|c|c|c|}
\hline WORK-FAMILY CONFLICT $(\alpha=0.894)$ & Mean & $\begin{array}{c}\text { Std. } \\
\text { Deviation }\end{array}$ \\
\hline $\begin{array}{l}\text { The demands of my job have effects on my home, family and } \\
\text { social life. }\end{array}$ & 2.7127 & 1.22278 \\
\hline $\begin{array}{l}\text { Due to my job, I can not maintain close relationships with family, } \\
\text { spouse/partner and friends. }\end{array}$ & 2.4400 & 1.13631 \\
\hline $\begin{array}{l}\text { The things I want to do at home I cannot do because of obligations } \\
\text { that my job imposes on me. }\end{array}$ & 2.5100 & 1.12660 \\
\hline $\begin{array}{l}\text { I often have to miss family and social gatherings because of my } \\
\text { job. }\end{array}$ & 2.7073 & 1.25891 \\
\hline $\begin{array}{l}\text { There is a conflict between my job and my responsibilities to } \\
\text { family, spous e/partner or friends. }\end{array}$ & 2.2918 & 1.10558 \\
\hline \multicolumn{3}{|l|}{ FAMILY - WORK CONFLICT $(\alpha=0.864)$} \\
\hline $\begin{array}{l}\text { The demands of my family, spouse/partner and friends interfere } \\
\text { with my job activities. }\end{array}$ & 2.0091 & 0.99677 \\
\hline Sometimes, I have to miss my job to fulfil family and social duties. & 2.1227 & 1.09612 \\
\hline $\begin{array}{l}\text { I fail to complete obligations at work due to family, } \\
\text { spouse/partner, friends. }\end{array}$ & 1.8691 & 0.98909 \\
\hline $\begin{array}{l}\text { My family and social life interfere with my job responsibilities } \\
\text { such as coming to work on time, completing work tasks, overtime. }\end{array}$ & 1.8545 & 0.99440 \\
\hline $\begin{array}{l}\text { My colleagues and associates do not like my preoccupation with } \\
\text { family and social life. }\end{array}$ & 1.9273 & 1.05628 \\
\hline \multicolumn{3}{|l|}{ EMOTIONAL EXHAUSTION $(\alpha=0.915)$} \\
\hline The job exhau & 2.6191 & 1.21314 \\
\hline I feel worn out at the end of the working day. & 3.0209 & 1.25702 \\
\hline $\begin{array}{l}\text { I feel tired when I get up in the morning and I have to face a long } \\
\text { day at work. }\end{array}$ & 2.8027 & 1.25182 \\
\hline Working with people all day is an effort for me. & 2.5036 & 1.16242 \\
\hline I feel tired from work. & 2.6973 & 1.17147 \\
\hline My job frustrates me. & 2.2682 & 1.15964 \\
\hline I feel like I work too hard at work. & 2.7655 & 1.18969 \\
\hline I feel that I am on the edge of my nerves. & 2.1991 & 1.18969 \\
\hline \multicolumn{3}{|l|}{ JOB PERFORMANCE $(\alpha=0.781)$} \\
\hline I commit to work. & 4.0182 & 1.10159 \\
\hline I am among the $10 \%$ of the best employees. & 3.4564 & 1.04968 \\
\hline I get along better with guests than other employees. & 3.1173 & 1.06558 \\
\hline I know more than others about the services provided to guests. & 3.1218 & 1.09581 \\
\hline I know better than others what the guests expect. & 3.0827 & 1.11873 \\
\hline \multicolumn{3}{|l|}{ TURNOVER INTENTIONS $(\alpha=0.917)$} \\
\hline I will probably look for another job soon. & 2.3555 & 1.18299 \\
\hline It would not take me long to leave this organization. & 2.3945 & 1.19095 \\
\hline I often think about leaving the organization. & 2.3297 & 1.20265 \\
\hline
\end{tabular}

Source: Author's research

In relation to the gender of the res pondents (Table 3 ), t-test showed that there are no notable differences between male and female respondents for all observed factors. Based on the obtained results, $\mathrm{H}_{1}$ and $\mathrm{H}_{2}$ were not confirmed. 
Table 3: T-test according to the gender of respondents

\begin{tabular}{|c|c|c|c|c|}
\hline Factors & $\begin{array}{c}\text { Male } \\
(\mathbf{n = 5 3 0})\end{array}$ & $\begin{array}{c}\text { Female } \\
(\mathbf{n = 5 7 0})\end{array}$ & t value & $\mathbf{p}$ \\
\hline WFC & 2.493 & 2.566 & 0.511 & 0.396 \\
\hline FWC & 1.951 & 1.962 & 0.986 & 0.708 \\
\hline EE & 2.547 & 2.668 & 0.248 & 0.716 \\
\hline JP & 3.378 & 3.342 & 0.389 & 0.842 \\
\hline TI & 2.316 & 2.402 & 0.385 & 0.700 \\
\hline
\end{tabular}

Source: Author's research

One-way analysis of variance examined whether there were differences in respondents' responses in relation to certain socio-demographic factors (age, level of education and marital status). ANOVA variance analy sis in relation to the age of the respondents (Table 4) determined the presence of significant differences in responses within the factors FWC, EE, JP and TI. No significant differences were found within WFC factor. This result did not provide support for $\mathrm{H}_{3}$. By applying LSD post-hoc test, it was determined between which age groups there are differences. Within the $\mathrm{FWC}$ factor $\mathrm{F}=7,828, \mathrm{p}=0.000$ ), it is evident that respondents from the category up to 25 years give significantly lower grades than respondents from all other age categories. Within the factor $\mathrm{EE}(\mathrm{F}=6,223, \mathrm{p}=0.000)$, it is noticeable that respondents from the category up to 25 years express a lower degree of emotional exhaustion compared to respondents from all other age categ ories. Within the factor JP $(\mathrm{F}=3,329, \mathrm{p}=0.016)$, respondents from the category up to 25 years give significantly lower grades than respondents from the categories 26 - 35 years and $36-45$ years. The last factor, $\mathrm{TI}(\mathrm{F}=3,064, \mathrm{p}=0.016)$ indicates that employees in the category of 46 - 55 years express significantly lower intention to leave the organization compared to younger employed respondents.

Table 4: ANOVA according to age

\begin{tabular}{|c|c|c|c|c|c|c|c|c|}
\hline \multirow[b]{2}{*}{ Factors } & \multicolumn{5}{|c|}{ Age groups } & \multirow[b]{2}{*}{$F$ value } & \multirow[b]{2}{*}{$\mathbf{p}$} & \multirow{2}{*}{$\begin{array}{l}\text { LSD post } \\
\text { hoc test }\end{array}$} \\
\hline & 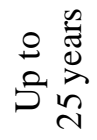 &  &  & 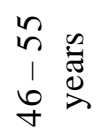 & 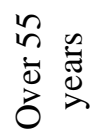 & & & \\
\hline$\overline{\mathrm{WFC}}$ & 2.331 & 2.529 & 2.613 & 2.553 & 2.629 & 2.305 & 0.057 & - \\
\hline$\overline{F W C}$ & 1.656 & 1.945 & 2.103 & 1.988 & 2.012 & 7.828 & 0.000 & $1<2,3,4,5$ \\
\hline $\mathrm{EE}$ & 2.333 & 2.561 & 2.764 & 2.669 & 2.773 & 6.223 & 0.000 & $1<2,3,4,5$ \\
\hline JP & 3.246 & 3.434 & 3.400 & 3.226 & 3.257 & 3.329 & $\overline{0.016}$ & $1<2,3$ \\
\hline TI & 2.417 & 2.347 & 2.478 & 2.158 & 2.095 & 3.064 & 0.016 & $4<1,2,3$ \\
\hline
\end{tabular}

Source: Author's research

Using the ANOVA test in relation to the level of education (Table 5), it was found that there is a notable difference only within the factor JP $(F=8,497, p=0.000)$. LSD post-hoc showed that employees with completed high school perceive a significantly lower work performance than those with a college or university degree, as well as those with a master's degree. The obtained results did not confirm $\mathrm{H}_{5}$ and $\mathrm{H}_{6}$. 
Table 5: ANOVA according to education level

\begin{tabular}{|c|c|c|c|c|c|c|c|}
\hline \multirow[b]{2}{*}{ Factors } & \multicolumn{4}{|c|}{ Education level } & \multirow[b]{2}{*}{ 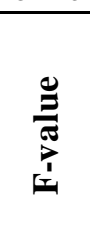 } & \multirow[b]{2}{*}{$\mathbf{p}$} & \multirow[b]{2}{*}{ 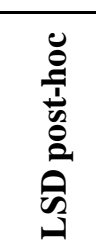 } \\
\hline & 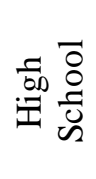 & 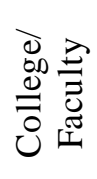 & 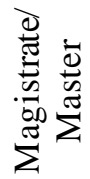 & $\stackrel{\vec{\Omega}}{\underline{a}}$ & & & \\
\hline WFC & 2.491 & 2.569 & 2.670 & 1.733 & 1.900 & 0.128 & - \\
\hline FWC & 1.940 & 1.987 & 1.955 & 1.733 & 0.320 & 0.811 & - \\
\hline $\mathrm{EE}$ & 2.560 & 2.641 & 2.579 & 1.833 & 0.860 & 0.461 & - \\
\hline JP & 3.255 & 3.480 & 3.538 & 3.600 & 8.497 & 0.000 & $1<2,3$ \\
\hline TI & 2.336 & 2.394 & 2.406 & 1.778 & 0.556 & 0.644 & - \\
\hline
\end{tabular}

Source: Author's research

Using marital status as an independent variable in the application of the ANOVA test, it was calculated that there was significant difference between the factors FWC $(\mathrm{F}=4,037, \mathrm{p}=$ $0.003), \mathrm{EE}(\mathrm{F}=2,557, \mathrm{p}=0.037)$ and $\mathrm{TI}(\mathrm{F}=3,084, \mathrm{p}=0.015)$. To determine among which groups of res pondents there are differences in responses, the LSD post-hoc test was applied (Table 6). In the case of the FWC, res pondents who are divorced express a higher level of this conflict than those who are married and unmarried. In terms of EE, married employees express a significantly lower level of exhaustion and burnout at work comp ared to divorced employees. The TI is least pronounced among married employees. The LSD post-hoc test indicated that those employees who are not married and those who are in other types of partnerships expres s a higher degree of turnover intention than employees who are married. The obtained results provided confirmation of $\mathrm{H}_{8}$. No significant difference was found within $W F C$, which did not confirm $\mathrm{H}_{7}$.

Table 6: ANOVA according to marital status

\begin{tabular}{|c|c|c|c|c|c|c|c|c|}
\hline \multirow[b]{2}{*}{ Factors } & \multicolumn{5}{|c|}{ Marital status } & \multirow[b]{2}{*}{ 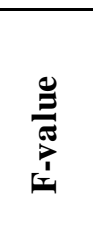 } & \multirow[b]{2}{*}{$\mathbf{p}$} & \multirow{2}{*}{ 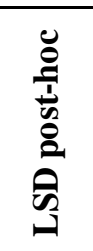 } \\
\hline & $\begin{array}{l}\cdot \stackrel{\vec{D}}{\Xi} \\
\sum \\
\sum\end{array}$ & 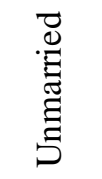 & 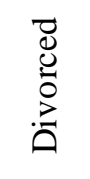 & $\begin{array}{l}0 \\
0 \\
0 \\
0 \\
0 \\
0 \\
3\end{array}$ & $\frac{\bar{\Xi}}{\stackrel{\Xi}{0}}$ & & & \\
\hline WFC & 2.531 & 2.477 & 2.791 & 2.378 & 2.758 & 2.287 & 0.058 & - \\
\hline FWC & 1.992 & 1.867 & 2.211 & 2.022 & 1.758 & 4.037 & 0.003 & $3>1,2$ \\
\hline $\mathrm{EE}$ & 2.631 & 2.523 & 2.839 & 2.715 & 2.809 & 2.557 & 0.037 & $1<3$ \\
\hline $\mathrm{JP}$ & 3.331 & 3.386 & 3.400 & 3.267 & 3.432 & 0.454 & 0.769 & - \\
\hline TI & 2.259 & 2.442 & 2.444 & 2.407 & 2.912 & 3.084 & 0.015 & $1<2,5$ \\
\hline
\end{tabular}

Source: Author's research

\section{Discussion and conclusions}

Nowadays, the conflict between family and work life is more and more frequent, and it is especially expressed in service activities such as the hotel industry with overtime work, inflexible working hours, work in shifts, but also work during holidays and weekends. Working with people is often very stressful, which is later projected onto other spheres of life. No matter how much effort is put into creating a balance between these two spheres, 32 
there will always be situations that will demand priority at some point. Reconciling work with private life is very important for the quality of life overall. The question is often as ked whether this conflict aris es because work takes too much time, so people overcome fatigue after a hard day, or it is difficult to concentrate on work due to family obligations. When it is not possible to strike a balance between these two spheres in an individual's life, there are numerous negative consequences - poor family relations hips, poorer performance at work, les s motivation to work and more. It is wrong to assume that the conflict between work and family life and the establis hment of a balancebetween these two spheres is a phenomenon that is unique to women. Als o, the experience of these conflicts should not be associated with the individual, because the problems caused by this conflict affect both the individual and the organization.

The findings of the conducted research show that gend er is not a significant indicator of differences in experiencing WFC, nor the intention to leave the organization. The $\mathrm{H}_{1}$ stems from the as sumption that gender has an influence on experiencing WFC, because women, although accomplished in the career, are still the ones who are most engaged in family life. By applying t-test according to gender it was found that there are no notable differences in experiencing WFC between males and females. These results did not give support for $\mathrm{H}_{1}$, but confirmed results obtained in previous studies (Akintay o, 2010; Frone, 2003; Karatepe et al., 2010). Given the fact that several studies identified the impact of gender on intention to leave an organization (Chen et al., 2018; Emiroğlu et al., 2015), in this study the authors tested if genderhas an influence on turnover intentions. Results showed no significant differences according to gender when it comes to intentions to leave an organ ization, which rejected $\mathrm{H}_{2}$. In several studies, no significant impact of gender on turnover intentions was found (Carbery et al., 2003; Yavas et al., 2008), so the results obtained in this study are in accordance with them. Taking into account the age of employees as a variable, it was found that significant differences exist in four of the five factors ( $F W C, E E, J P$ and $T I)$. As in the study of Karatepe et al. (2010), in this study no significant differences were found in responses related to WFC according to age, which rejected $\mathrm{H}_{3}$. With reference to turnover intentions, younger employees express a higher degree of turnover intention comp ared to older ones, which is in accordance with previous studies (Blomme et al., 2010; Carbery et al., 2003; Karatepe et al., 2006; Kim et al., 2010; Pizam \& Thornburg, 2006). As an alternative explanation for such results, the fact of greater readiness of young people for new experiences and easier spatial and business change could be mentioned. This confirms $\mathrm{H}_{4}$.

The level of education proved to be significant only for the JP factor. Respondents with completed high school perceive their work performance lower than employees with higher education. Highly educated employees are mostly engaged in performing more complex work tas ks, which results in a higher perception of their own performance. Employees with a lower level of education usually perform operational tasks, which require fewer skills and qualifications, and therefore the perception of work performance is lower. Since the literature recognized the influence of education level on WFC (Adams et al., 1996; Anafarta \& Kuruïzüm, 2012), in this study no evident relationship between education level and WFC was determined. These results rejected $\mathrm{H}_{5}$. Based on results of many studies (i.e. Carbery et al., 2003; Karatepe et al., 2006), the initial as sumption was that highly educated employees express a higher degree of turnover intention. In this study no significant impact of education level on turnover intention was found, which did not provide sup port for $\mathrm{H}_{6}$. Although several studies found relationship between marital status and WFC (Beutell, 2010; Mukanzi \& Senaji, 2017; Rathi \& Barath, 2013), the findings of this research showed no notable relations hip between marital status and WFC, which rejected $\mathrm{H}_{7}$. However, obtained results are in line with the results of Liu et al. (2020) study, who found no significant association between marital status and experiencing WFC. When it comes to the relationship between 
marital status and intentions to leave an organization, some papers point out that the level of turnover intention is higher among single people than among married people (Carbery et al., 2003; Emiroğlu et al., 2015). The obtained results indicate that married respondents have lower intention to leave the organization than single ones, which confirms $\mathrm{H}_{8}$. These findings could be possibly explained by the fact that married employees do not make eas y decisions to leave the organization, especially if there are children in the family, because it would jeopardize financial stability.

The recommendation for future research is to includevariables such as job satisfaction and work autonomy (Gözükara \& Çolakoğlu, 2016), a type of work and spousal support (Gamor et al., 2014) as well as different cultural backgrounds in order to contribute to the literature in this field, as well as a more complete understanding of this phenomena in the hotel industry.

\section{Conflict of interest}

The authors declare no conflict of interest.

\section{References}

1. Adams, G. A., King, L. A., \& King, D. W. (1996). Relationships of job and family involvement, family social support, and work-family conflict with job and life satisfaction. Journal of Applied Psychology, 81(4), 411-420. https://doi.org/10.1037/0021-9010.81.4.411

2. Akintayo, D. I. (2010). Managerialeffectiveness: Impact of emotional intelligence and work-family role conflict in work organizations in Nigeria. Eastern Africa Social Science Research Review, 26, 23-40. http://dx.doi.org/10.1353/eas.0.0016

3. Anafarta, N., \& Kuruüzüm, A. (2012). Demographic predictors of work-family conflict for men and women: Turkish case. International Journal of Business and Management, 7(13), 145-158. https://doi.org/10.5539/ijbm.v7n 13p145

4. Andreassi, J. K., \& Thompson, C. A. (2007). Dispositional and situational sources of control: Relative impact on work-family conflict and positive spillover. Journal of Managerial Psychology, 22(8), 722-740. https://doi.org/10.1108/02683940710837697

5. Beutell, N. J. (2010). Work schedule, work schedule control and satis faction in relation to work-family conflict, work-family synergy, and domain satisfaction. Career Development International, 15, 501-518. https://doi.org/10.1108/13620431011075358

6. Blomme, R. J., Van Rheede, A., \& Tromp, D. M. (2010). Work-family conflict as a cause for turnover intentions in the hospitality industry. Tourism and Hospitality Research, 10(4), 269-285. https ://doi.org/10.1057/thr.2010.15

7. Carbery, R., Garavan, T. N., O’Brien, F., \& McDonnell, J. (2003). Predicting hotel managers' turnover cognitions. Journal of Managerial Psychology, 18(7), 649-679. https://doi.org/10.1108/02683940310502377

8. Carnicer, M. P., Sánchez, A. M., \& Pérez, M. P. (2004). Work-family conflict in a southern European country. Journal of Managerial Psychology, 19, 466-489. http://dx.doi.org/10.1108/02683940410543579

9. Chen, H., Ayoun, B., \& Eyoun, K. (2018). Work-family conflict and turnover intentions: A study comparing China and U.S. hotel employees. Journal of Human Resources in $\begin{array}{llll}\text { Hospitality } \quad \text { T } & \text { Tourism, }\end{array}$ https://doi.org/10.1080/15332845.2017.1406272

10. Choi, H. J., \& Kim, Y. T. (2012). W ork-family conflict, work-family facilitation, and job outcomes in the Korean hotel industry. International Journal of Contemporary Hospitality Management, 24(7), 1011-1028. https://doi.org/10.1108/09596111211258892 
11. Duxbury, L., \& Higgins, C. (2001). Work-life balance in the new millennium: Where are we? Where do we need to go? CPRN Discussion Paper. Canadian Policy Research Networks Inc., Ottawa (Ontario).

12. Emiroğlu, B. D., Akova, O., \& Tanrıverdi, H. (2015). The relationship between turnover intention and demographic factors in hotel businesses: A study at five star hotels in Istanbul. Procedia-Social and Behavioral Sciences, 207, 385-397. https://doi.org/10.1016/j.sbs pro.2015.10.108

13. Fiksenbaum, L., Jeng, W., Koyuncu, M., \& Burke, R. J. (2010). Work hours, work intensity, satisfactions and psychological well-being among hotel managers in China. Cross Cultural Management, 17, 79-93. https://doi.org/10.1108/13527601011016925

14. Frankenhaeuser, M., Lundberg, U., Fredriks on, M., Melin, B., Tuomisto, M., Myrsten, A.-L., ... Wallin, L. (1989). Stress on and off the job as related to sex and occupational status in white-collar workers. Journal of Organizational Behavior, 10(4), 321-346. https://doi.org/10.1002/job.4030100404

15. Frone, M. R. (2003). Work-family balance - Handbook of occupational health psychology (pp. 143-162). Washington, USA: American Psychological Association.

16. Furnham, A. (2002, February 5). Happy staff is not the full ans wer: Management style can be reflected in customer service - but the relationship is complex. Financial Times, p. 16.

17. Gamor, E., Amis sah, E. F., \& Boakye, K. A. A. (2014). Work-family conflict among hotel employees in Sekondi-Takoradi Metropolis, Ghana. Tourism Management Perspectives, 12, 1-8. https://doi.org/10.1016/j.tmp.2014.06.001

18. Gordon, J. R., \& Berry-Whelan, K. S. (2007). The relationship among work-family conflict and enhancement, org anizational culture and work outcomes for older working women. Journal of Occupational Health Psychology, 12, 350-364. https://doi.org/10.1037/1076-8998.12.4.350

19. Gözükara, İ., \& Çolakoğlu, N. (2016). The mediating effect of work family conflict on the relationship between job autonomy and job satisfaction. Procedia-Social and Behavioral Sciences, 229, 253-266. https://doi.org/10.1016/j.s bs pro.2016.07.136

20. Grzywacz, J. G, \& Marks, N. F. (2000) Family, work, work-family spillover, and problem drinking during midlife. Journal of Marriage and Family, 62(2), 336-348. https://doi.org/10.1111/j.1741-3737.2000.00336.x

21. Hsu, Y. R. (2011). Work-family conflict and job satisfaction in stressful working environments. International Journal of Manpower, 32(2), 233-248. https://doi.org/10.1108/01437721111130224

22. Kaiser, H. F. (1974). An index of factorial simplicity. Psychometrika, 39(1), 31-36. https://doi.org/10.1007/BF02291575

23. Karatepe, O. M., Sokmen, A., Yavas, U., \& Babakus, E. (2010). Work-family conflict and burnout in frontline service jobs: Direct, mediating and moderating effects. Ekonomie a Management [Economics and Management], 13(4), 61-73. http://hdl.handle.net/11025/17366

24. Karatepe, O. M., Uludag, O., Menevis, I., Hadzimehmedagic, L., \& Baddar, L. (2006). The effects of selected individual characteris tics on frontline employee performance and job satisfaction. Tourism Management, 27, 547-560. https://doi.org/10.1016/j.tourman.2005.02.009

25. Kim, B. P., Lee, G., Carlson, K. D. (2010). An examination of the nature of the relationship between leader-member-exchange (LMX) and turnover intent at different organizational levels. International Journal of Hospitality Management, 29, 591-597. https://doi.org/10.1016/j.ijhm.2009.10.025

26. Liu, C., Cao, J., Zhang, P., \& Wu, G. (2020). Investigating the relationship between work-to-family conflict, job burnout, job outcomes, and affective commitment in the 
construction industry. International Journal of Environmental Research and Public Health, 17(16), 5995. https://doi.org/10.3390/ijerph17165995

27. Lundberg, U., Mardberg, B., \& Frankenhaeuser, M. (1994). The total workload of male and female white collar workers as related to age, occupational level, and number of children. Scandinavian Journal of Psychology, 35(4), 315-327. https://doi.org/10.1111/j.1467-9450.1994.tb00956.x

28. Mjoli, T., Dywili, M., \& Dodd, N. (2013). Demographic determinants of work-family conflict among female factory workers in South Africa. Journal of Economics, Business and Management, 1(1), 30-41. https ://doi.org/10.7763/JOEBM.2013.V1.9

29. Mukanzi, C. M., \& Senaji, T. A. (2017). Work-family conflict and employee commitment: The moderating effect of perceived managerial support. SAGE Open, 7(3), 1-12. https://doi.org/10.1177/2158244017725794

30. Netemeyer, R. G., Boles, J. S., \& McMurrian, R. (1996). Development and validation of work-family conflict and family-work conflict scales. Journal of Applied Psychology, 81(4), 400-410. https://doi.org/10.1037/0021-9010.81.4.400

31. Netemeyer, R. G., Johnston, M. W., \& Burton, S. (1990). Analysis of role conflict and role ambiguity in a structural equations framework. Journal of Applied Psychology, 75(2), 148-157. http://dx.doi.org/10.1037/0021-9010.75.2.148

32. Netemeyer, R. G., Maxham, J. G., III, \& Pullig, C. (2005). Conflicts in the work family interface:Links to job stress, customer service employee performance, and customer purchase intention. Journal of Marketing, 69(2), 130-143. https://doi.org/10.1509/jmkg.69.2.130.60758

33. O'Dris coll, M., Brough, P., \& Kalliath, T. (2006). Work-family conflict and facilitation. In F. Jones et al. (Eds.), Work-life Balance: A Psychological Perspective (pp. 117-142). Hove: Psychological Press.

34. Pizam, A., \& Thornburg, S. W. (2000). Absenteeismand voluntary turnover in Central Florida hotels: A pilot study. Hospitality Management, 19, 211-217. https://doi.org/10.1016/S0278-4319(00)00011-6

35. Poelmans, S. A., Chinchilla, N., \& Cardona, P. (2003). The adaption of family-friendly HRM policies: Competing for scarce resources in the labour market. International Journal of Manpower, 24(2), 128-147. https ://doi.org/10.1108/01437720310475394

36. Rathi, N., \& Barath, M. (2013). Work-family conflict and job and family satisfaction: Moderating effect of social support among police personnel. Equality, Diversity and Inclusion: An International Journal, 32, 438-454. https ://doi.org/10.1108/EDI-10-20120092

37. Tromp, D. M., \& Blomme, R. J. (2014). Leadership style and negative work-home interference in the hospitality industry. International Journal of Contemporary Hospitality Management, 26, 85-106. https://doi.org/10.1108/IJCHM-04-2012-0058

38. Turliuc, M., \& Buliga, D. (2014). Work-family conflict and job and family satisfaction. The mediating role of cognitions. Procedia-Social and Behavioral Sciences, 159, 105109. https://doi.org/10.1016/j.sbspro.2014.12.338

39. Yavas, U., Babakus, E., \& Karatepe, O.M. (2008). Attitudinal and behavioral consequences of work-family conflict and family-work conflict: Does gender matter? International Journal of Service Industry Management, 19(1), 7-31. https ://doi.org/10.1108/09564230810855699

Received:9June 2021; Sent for revision: 3 July 2021; Accepted: 27 August 2021 